\title{
Using the UTAUT model to understand students' usage of e-learning systems in developing countries
}

\author{
Muneer M. M. Abbad ${ }^{1}$ (D)
}

Received: 8 December 2020 / Accepted: 30 April 2021 / Published online: 15 May 2021

(C) The Author(s), under exclusive licence to Springer Science+Business Media, LLC, part of Springer Nature 2021

\begin{abstract}
Research on information systems has identified a variety of factors across a range of adoption models that determine their acceptance. In this research, the unified theory of acceptance and use of technology (UTAUT), which integrates determinants across eight models, was utilised to analyse students' intentions to use and their actual usage of Moodle, an e-learning system at Hashemite University, a public university in Jordan, one of developing countries. Four principal determinants of intention and usage were explored: performance expectancy, effort expectancy, social influence, and facilitating conditions. Data were collected from 370 undergraduate students and analysed using structural equation modelling techniques. The results indicated that performance expectancy and effort expectancy affected behavioural intentions to use Moodle whereas social influence did not. In addition, the results confirmed the direct impact of behavioural intentions and facilitating conditions on students' use of Moodle. UTAUT thus provides a valuable tool that enables university decision makers, faculty members, and designers to understand the factors driving e-learning system acceptance and thus facilitate the adoption of the system by students. The study will help educational institutions prepare e-learning systems, which is especially important during a state of emergency such as that caused by COVID-19.
\end{abstract}

Keywords UTAUT $\cdot$ E-learning $\cdot$ Technology acceptance $\cdot$ Developing countries · Jordan

Muneer M. M. Abbad

Muneer.abbad@ccq.edu.qa

1 Department of Business, Community College of Qatar, Doha, Qatar 


\section{Introduction}

The number of global Internet users has expanded at an exponential rate. Internet World Stats (2020) indicate there are now more than 4.8 billion users worldwide, 184 million of whom are in the Middle East. In response to this, a large number of universities have identified opportunities to develop courses for web-based learning. In addition, the rapid advancement of IT has made it possible to offer learning content in a variety of formats that can be delivered through the Internet, intranet, extranet, or other electronic channels. In its early phases, web-based learning encountered technological problems that limited access and communication (Chin, 1999). As it advanced, these were superseded by problems concerning learners who felt isolated and lacked motivation, structure, and guidance. A key area of focus has been learners' satisfaction, which some scholars have characterised as being one-dimensional (Johnson et al., 2000). By contrast, Chang and Cheung (2001) argued that satisfaction is a multi-dimensional construct comprising perceptions, beliefs, attitudes, and engagement with online course material. Bonk (2016) argued that learning today is more personal, digital, comfortable, blended, visual, and game-based.

Successful e-learning uptake is contingent on understanding how users accept technology (Ashraf et al., 2016) and how such technology is influencing every aspect of learning and education (Al Mulhem, 2020). This is especially salient in developed countries. The International Telecommunication Union (2017) reported that more than $80 \%$ of global youths online live in 104 countries. The figure is higher for developed countries where $94 \%$ of those aged 15-24 use the Internet compared with $67 \%$ in developing countries. This suggests that developing regions can benefit significantly from the Internet and IT yet have received comparably limited research attention (Al-Adwan et al., 2018). Nevertheless, several developing countries (e.g., Jordan, Thailand, and Indonesia) are implementing e-learning courses to increase the quality of learning (Al-Adwan et al., 2018; Kim \& Park, 2018). However, they face greater challenges than developed countries due to a lack of human and technical infrastructure, low acceptance of technology, and inadequate institutional cooperation and information sharing (Kim \& Park, 2018). Farid et al. (2015) argue that e-learning systems as a new approach to teaching are not gaining popularity in developing countries despite investment in education and technological advancement.

Thus, the main aim of this study is to explore the factors that affect students' adoption of e-learning systems in developing countries. It draws upon the unified theory of acceptance and use of technology (UTAUT), a model that integrates determinants across a range of technology acceptance models. This and other related studies are especially important given the emergence of COVID-19 that has motivated educational institutions across the world to use e-learning systems and to review their standard face-to-face approach to teaching. 


\subsection{E-learning in higher education}

The increasing prevalence of technology in daily life underscores the growing importance of e-learning in higher education. E-learning has attracted considerable interest among researchers (Lew et al., 2019; Vasconcelos et al., 2020; Vershitskaya et al., 2020). This is because it has the ability to transform learning and broaden its scope to reach more people. By disseminating education to a wider populace, it has the potential to offer better standards of living. E-learning is now becoming a regular feature of higher education (Navarrete et al., 2016). It overcomes the limits on education created by time and distance and provides a greater number of opportunities for more people to learn (Moreira et al., 2017). As such, e-learning is empowering, efficient, cost-friendly, and sustainable (Abdekhoda et al., 2016).

E-learning is considered by many scholars to constitute a digital revolution and a significant breakthrough in education (Rawat \& Dwivedi, 2019; Martínez-Cerdá et al., 2020). It enhances the learning process by providing an innovative virtual environment and increases levels of satisfaction among students (Violante \& Vezzetti, 2015). E-learning supports information sharing and creates learning opportunities for the disadvantaged and those living in remote locations (Webster \& Hackley, 1997). Additionally, it facilitates connectivity between different parts of the world and between instructors and learners while also providing an environment and tools that support creativity and innovation (Violante \& Vezzetti, 2015).

In summary, e-learning can be understood in terms of the what, how, and why:

What: It consists of information and instructional techniques designed to help people learn.

How: The course content is delivered in the virtual space and makes full use of all types of learning materials and mediums.

Why: E-learning courses help people achieve their educational objectives and support on-the-job learning by providing diverse communication tools and flexible learning options.

Despite its numerous advantages, it is important not to over-emphasise its benefits. For instance, some scholars tend to view e-learning as a panacea for all educational challenges (Biggs, 2003). E-learning is not just about presenting information differently; it is about embracing the new reality in terms of how people live their lives. It is a recognition of human advancement and the product of a globalised village of interconnected actors. Additionally, Biggs (2003: 23) argues that: "if students are to learn desired outcomes in a reasonably effective manner, then the teacher's fundamental task is to get the students to engage in learning activities that are likely to result in their achieving those outcomes....what the student does in determining what is learned is more important than what the teacher does". Therefore, teachers need to be more cognisant of the need to promote learning rather than themselves as 'experts'. For example, if students perceive interaction as important, then it is essential to ensure they are afforded the opportunity to interact and engage with each other as part of a deep and 
meaningful learning experience. According to Ramsden (1998), there is substantial evidence to suggest students' perceptions of teaching have a profound impact on their approaches to learning and the quality of what they learn.

The success of e-learning systems (e.g., Moodle) is dependent on their usage and acceptance by students and instructors that, if high, will increase the return on the investments higher education institutions make in such systems (Sharma et al., 2017). Moodle is one of the most favoured and widely used learning management systems due to its rich functionality and open-source nature. It currently hosts over 8 million courses serving more than one million instructors and in excess of 76 million students (Rawat \& Dwivedi, 2019).

\subsection{Research objectives}

Over the last two decades, researchers have investigated people's intentions to use and acceptance of new technologies (Fillion et al., 2012). Behavioural intention refers to the willingness of individuals to perform a specific job (Chu \& Chen, 2016). Technology acceptance refers to whether and why individuals adopt technology (Louho et al., 2006), while adoption refers to its continued use (Sathye, 1999). In the context of e-learning, intention refers to the adoption and acceptance of new technologies that will be utilised in future learning processes (Sánchez-Prieto et al., 2017). Users are free to decide which technology they want to use. As such, understanding the factors that drive this decision goes a long way towards facilitating the design of technologies that will have real-world applications. Greater technological acceptance by an individual signifies a willingness to change their lifestyle by utilising the innovation in their lives (Succi \& Walter, 1999). Accordingly, it is a vital determinant of whether technology will succeed (Davis, 1993). Conversely, a lack of acceptance risks the failure and loss of technology (Gould \& Lewis, 1985; Nickerson, 1981).

Developing countries generally have limited resources, inadequate funds, poor administrative and technical support, and limited staff development which prevents them from utilising new technologies effectively and integrating these into their education systems (Al-Adwan et al., 2018; Kim \& Park, 2018; Deb, 2011). In Jordan, e-learning has been officially incorporated into higher education institutions and a variety of technologies are now being utilised by students and faculty members (Al-Adwan et al., 2018). However, the adoption of e-learning systems in Jordanian higher education institutions remains below that of comparable international institutions (Almarabeh \& Mohammad, 2013; Jaber, 2016). Therefore, to increase the successful adoption of e-learning, several factors pertinent to higher education must be addressed, most important of which are those that impact on levels of students' acceptance (Thomas et al., 2013; Sharma et al., 2017).

This study identifies the reasons why students at Hashemite University in Jordan accept the use of the learning management system (LMS) known as Moodle. Moodle is a platform offering multiple services such as learning and teaching 
materials, assessments, and forums. It is the face of e-learning at Hashemite University and the platform from which students download the necessary learning materials, interact with other students and teachers, submit their completed assignments, and are assessed. The staff use Moodle as a management tool to organise their classes and the corresponding coursework. It enables them to communicate with students and ensure they are progressing as intended. At Hashemite University, the use of Moodle is not mandatory for instructors and students. Nevertheless, instructors are using Moodle to supplement their traditional teaching. This study draws upon the unified theory of acceptance and use of technology (UTAUT) model developed by Venkatesh et al. (2003) to analyse behavioural intentions to use and actual usage of Moodle. The data were analysed using structural equation modelling (SEM).

\subsection{Theoretical framework}

This study explores technology adoption among students in terms of how they receive the e-learning system (Moodle). This section reviews technology acceptance theories and selects the theory most appropriate for this research.

To date, four major models of technology adoption have been proposed. The first is the theory of reasoned action (TRA) (Fishbein \& Ajzen, 1975) and its extended successor, the theory of planned behaviour (TPB) (Ajzen, 1985). These theories view a person's intention to perform a behaviour as an immediate determinant of whether such an action takes place. TPB extends TRA by including perceived behavioural control as a determinant of behaviour. The second model is the technology acceptance model (TAM) (Davis, 1986) which posits perceived usefulness (PU) and perceived ease of use (PEOU) as determinants of the intention to use technology, which then influences acceptance behaviour. The third model, known as TAM2, extends TAM by adding social influence (subjective norm) and cognitive instrumental processes (Venkatesh \& Davis, 2000). The final model is the innovation diffusion theory (IDT) (Rogers, 1983) which posits five determinants of innovation adoption: relative advantage, complexity, compatibility, trialability, and observability. Collectively, these models encompass the immediate and indirect effects on actual usage behaviour. Table 1 summarises these models.

Venkatesh et al. (2003) combined these and other models (e.g. the motivation model and PC utilisation) to form an integrated theory of technology acceptance called unified theory of acceptance and use of technology (UTAUT). Venkatesh et al. (2003) found the model to account for only $70 \%$ of the variance in behavioral intention to use and only about $50 \%$ in actual use (Venkatesh et al., 2012). However, Dwivedi et al. (2019) stated that UTAUT model omitted some possibly significant relationships, hypothesized some relationships that may not be appropriate to all situations, and removed some constructs that may be critical for explaining information systems acceptance and use. 


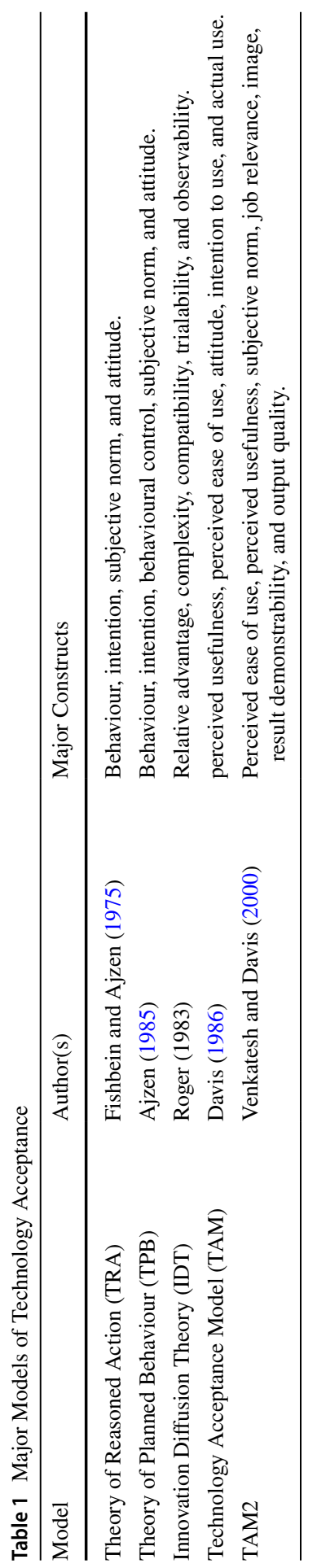


Venkatesh et al. (2003) utilised UTAUT model to understand human acceptance behaviour across a range of disciplines. This study utilises this model, which integrates the following factors (Venkatesh et al., 2003, p. 447-453):

1- Performance Expectancy (PE): This refers to "the degree to which an individual believes that using the system will help him or her to attain gains in job performance".

2- Social Influence (SI): This refers to "the degree to which an individual perceives that important others believe he or she should use the new system".

3- Effort Expectancy (EE): This refers to "the degree of ease associated with the use of the system".

4- Facilitating Conditions (FC): This refers to "the degree to which an individual believes that an organisational and technical infrastructure exists to support the use of the system".

In the UTAUT (Fig. 1), performance expectancy, effort expectancy, and social influences are directly assoiated with behavioural intentions while the final facilitating conditions are associated with actual usage. In addition, behavioural intentions are influenced by gender, age, experience, and voluntariness.

To apply the model in the context of e-learning, Jaradat and Banikhaled (2013) modified it by including the quality of the website as a factor they argued was significantly associated with the intention to use. Nassuora (2012) employed the UTAUT to analyse the acceptance of mobile learning and focused on attitudes rather than intention behaviour. Salim (2012) explored e-learning acceptance on Facebook while Gogus and Nistor (2012) applied the model to

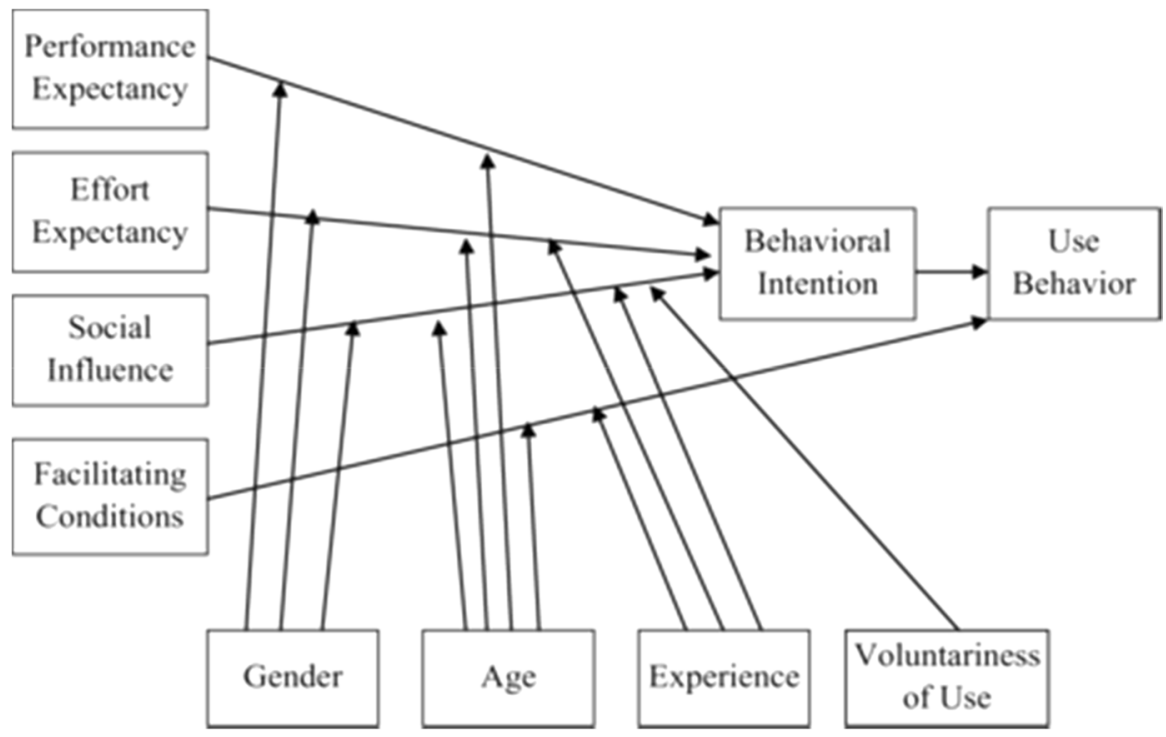

Fig. 1 UTAUT Model 
the Turkish educational system to examine online communication and interaction. To assess the adoption of e-learning among academicians, Uğur and Turan (2018) extended the UTAUT by adding two new determinants: the area of scientific expertise and system interactivity. Kim and Lee (2020) recently used the UTAUT as a base model in the Philippines to build a conceptual model of effective ICT-based instruction.

\subsection{Research methodology and data analysis}

The UTAUT was used to explore students' acceptance of e-learning at Hashemite University. The factors that were explored as determinants of acceptance behaviour were performance expectancy, social influence, effort expectancy, and facilitating conditions. According to Dwivedi et al. (2019), most studies only used a subset of the UTAUT model, and moderators were frequently dropped. They mentioned that previous research may not have used moderators because there may not be any difference in the moderator for the adoption and usage context. The modified version of the model is presented in Fig. 2.

Based on the UTAUT, the following five hypotheses were formulated and tested (H1-H5):

H1: Performance expectancy will affect the behavioural intention.

$\mathrm{H} 2$ : Effort expectancy will affect the behavioural intention.

H3: Social influence will affect the behavioural intention.

H4: Facilitating condition will affect the use behaviour.

H5: Behavioural intention will affect the use behaviour.

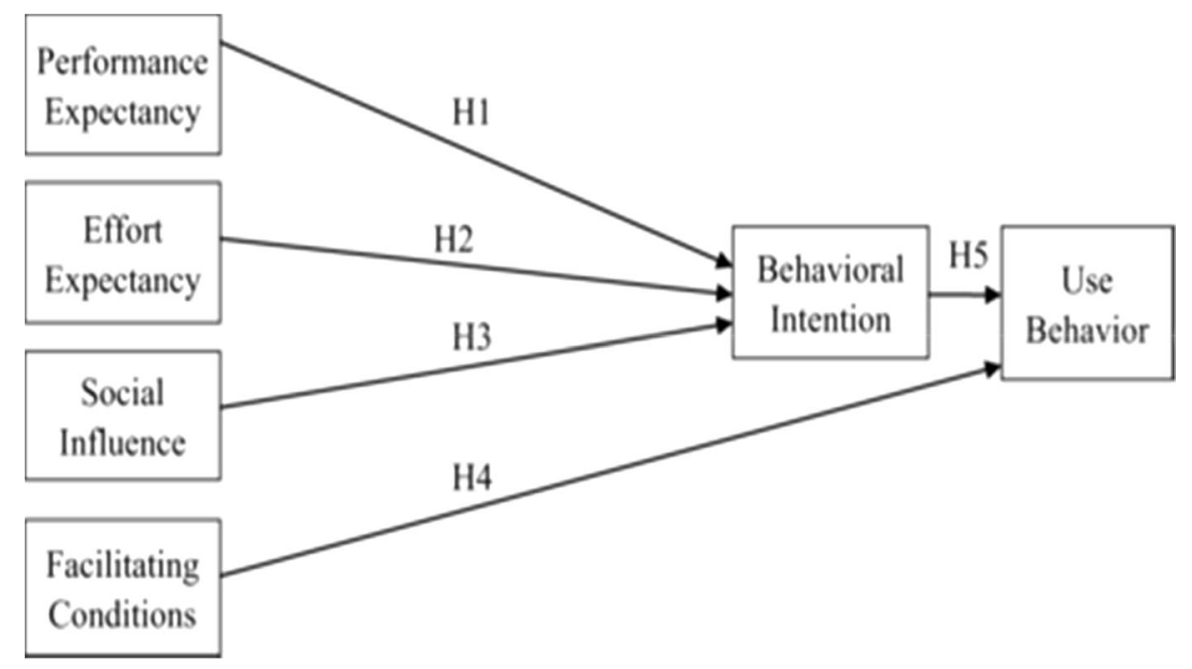

Fig. 2 Modified UTAUT 
Like the theory of reasoned action (TRA), behavioural intention (IU) helps capture the reasons underlying students' acceptance of technology (Maldonado et al., 2011; Park, 2009). In the UTAUT, usage behaviour is affected by facilitating conditions (FC). These comprise performance expectancy (PE), effort expectancy (EE), social influence (SI), and facilitating conditions (FC). PE refers to students' belief that e-learning will help them achieve their educational goals. EE refers to the ease of using the e-learning system. SI refers to the perceived importance of the e-learning system. Finally, FC denotes the degree to which students believe personal or organisational resources facilitate the use of the e-learning system.

\section{Methodology}

Convenience sampling was employed to collect the required data. This involved faculty members in three colleges (Business, IT, and Engineering) at Hashemite University distributing paper-based questionnaires to their students. In total, 400 questionnaires were distributed and 380 responses were received, of which 10 were excluded due to missing data. Based on the recommendations of Hair et al. (2006) the sample size should be 15-20 observations per variable for generalizability purposes. The total number of variables in this study was six, including the actual use of the e-learning system. Therefore, the sample size was considered adequate.

The sample comprised undergraduate students enrolled in different colleges (38.4\% Business, 32.4\% IT, 26.8\% Engineering, and 2.4\% others) and distributed almost equally across four different levels (level 1, level 2, level 3, and level 4) (see

Table 2 Demographic characteristics of the sample

\begin{tabular}{lll}
\hline Variable & Number of Respondents & Percent (\%) \\
\hline Gender & & \\
$\quad$ Male & 154 & 41.6 \\
Female & 216 & 58.4 \\
Age & & \\
18-20 years & 162 & 43.8 \\
21-23 years & 147 & 39.7 \\
Above 23 years & 61 & 16.5 \\
Your level & & \\
$\quad$ Year one & 84 & 22.7 \\
Year two & 92 & 24.9 \\
Year three & 96 & 25.9 \\
Year four & 98 & 26.5 \\
College & & \\
Business & 142 & 38.4 \\
IT & 120 & 32.4 \\
Engineering & 99 & 26.8 \\
Others & 9 & 2.4 \\
\hline
\end{tabular}




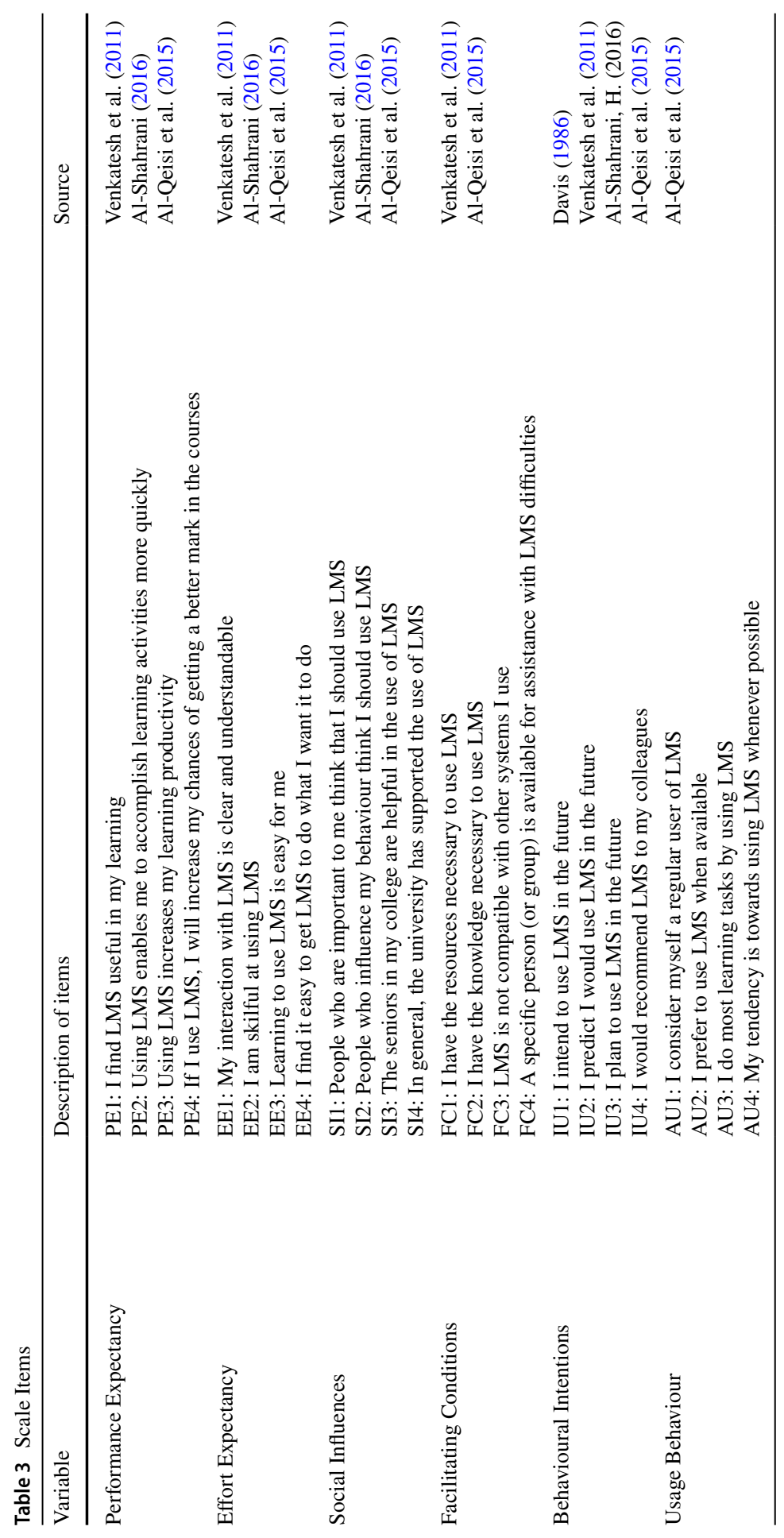


Table 2). All the necessary materials for students were available on Moodle, including syllabuses, PowerPoint presentations, homework, videos, reading references, and discussion forums. Data collection began three weeks before the final exam to ensure students were sufficiently experienced in using Moodle. As shown in Table 2, $58.4 \%$ of participants were female and $41.6 \%$ were male. In terms of age, $43.8 \%$, were $18-20$ years, $39.7 \%$ 20-23 years, and $16.5 \%$ participants above 23 years.

All UTAUT factors were measured by the items listed in Table 3, which were developed by the authors of the UTAUT model (Venkatesh et al., 2003, 2011) and other well-established studies that have applied UTAUT to mobile learning (AlShahrani, 2016) and e-banking (Al-Qeisi et al., 2015). Actual use was measured by using self-report questionnaire since the actual use of the system could not be captured using the users' log file. According to Johnson et al. (2014), measuring actual system use is difficult because actual system use can be difficult to identify and this type of information is often unavailable to researchers.

In total, 24 items were measured on a seven-point Likert-type scale $(1=$ strongly disagree $7=$ strongly agree). The questionnaire was first translated from English to Arabic using back translation. It was also pre-tested on a representative sample of 45 students. Finally, the research instrument was approved by three experts on e-learning and information systems.

\section{Data analysis and results}

Structural equation modelling (SEM) techniques were used to analyse the data and test the hypotheses. The analysis was performed using the two-step approach developed by Anderson and Gerbing (1988). The first step involved assessing the validity and reliability of the measurement model while the second step involved analysing the structural model to test the research hypotheses.

Table 4 CFA Statistics of Model Fit

\begin{tabular}{lll}
\hline Goodness-Fit Indexes & $\begin{array}{l}\text { Recommended } \\
\text { Value }\end{array}$ & Result Model \\
\hline CMIN /df & $\leq 3.00$ & 1.370 \\
Goodness-of-fit index (GFI) & $\geq 0.90^{*}$ & 0.896 \\
Incremental fit index (IFI) & $\geq 0.90$ & 0.969 \\
Adjusted goodness-of-fit index (AGFI) & $\geq 0.80$ & 0.852 \\
Comparative fit index (CFI) & $\geq 0.90$ & 0.968 \\
Root mean square error of approximation & $\leq 0.08$ & 0.050 \\
$\quad$ RMSEA) & & \\
\hline
\end{tabular}

*GFI $\geq 0.8$ According to Forza and Filippini (1998) and Greenspoon and Saklofske (1998) 
Table 5 Reliability and Convergent Validity Coefficients

\begin{tabular}{|c|c|c|c|c|c|c|}
\hline Factor & Variables & $\begin{array}{l}\text { Standard- } \\
\text { ised Load- } \\
\text { ings } \\
(>0.707)\end{array}$ & $\begin{array}{l}\text { Reliability } \\
\left(\mathrm{R}^{2}\right) \\
(>0.5)\end{array}$ & $\begin{array}{l}\text { AVE } \\
(>0.5)\end{array}$ & $\begin{array}{l}\text { Composite } \\
\text { Reliability } \\
(\mathrm{CR}) \\
(>0.7)\end{array}$ & $\begin{array}{l}\text { Cronbach's Alpha } \\
(>0.7)\end{array}$ \\
\hline \multirow{3}{*}{$\begin{array}{l}\text { Performance } \\
\text { Expectancy } \\
(\mathrm{PE})\end{array}$} & PE1 & 0.722 & 0.521 & \multirow[t]{3}{*}{0.639} & \multirow[t]{3}{*}{0.841} & \multirow[t]{3}{*}{0.821} \\
\hline & PE2 & 0.869 & 0.755 & & & \\
\hline & PE3 & 0.800 & 0.640 & & & \\
\hline \multirow{3}{*}{$\begin{array}{l}\text { Effort Expectancy } \\
\text { (EE) }\end{array}$} & EE1 & 0.771 & 0.594 & \multirow[t]{3}{*}{0.663} & \multirow[t]{3}{*}{0.855} & \multirow[t]{3}{*}{0.852} \\
\hline & EE2 & 0.841 & 0.707 & & & \\
\hline & EE3 & 0.829 & 0.687 & & & \\
\hline \multirow{2}{*}{$\begin{array}{l}\text { Social Influences } \\
\text { (SI) }\end{array}$} & SI3 & 0.708 & 0.501 & \multirow[t]{2}{*}{0.652} & \multirow[t]{2}{*}{0.787} & \multirow[t]{2}{*}{0.817} \\
\hline & SI4 & 0.896 & 0.803 & & & \\
\hline \multirow{3}{*}{$\begin{array}{l}\text { Facilitating Condi- } \\
\text { tions } \\
\text { (FC) }\end{array}$} & FC1 & 0.829 & 0.687 & \multirow[t]{3}{*}{0.690} & \multirow[t]{3}{*}{0.870} & \multirow[t]{3}{*}{0.741} \\
\hline & $\mathrm{FC} 2$ & 0.861 & 0.741 & & & \\
\hline & FC3 & 0.801 & 0.642 & & & \\
\hline \multirow{4}{*}{$\begin{array}{l}\text { Behavioural Inten- } \\
\text { tions } \\
\text { (IU) }\end{array}$} & IU1 & 0.812 & 0.659 & \multirow[t]{4}{*}{0.672} & \multirow[t]{4}{*}{0.891} & \multirow[t]{4}{*}{0.888} \\
\hline & IU2 & 0.854 & 0.729 & & & \\
\hline & IU3 & 0.874 & 0.764 & & & \\
\hline & IU4 & 0.731 & 0.534 & & & \\
\hline \multirow{3}{*}{$\begin{array}{l}\text { Usage Behaviour } \\
\text { (AU) }\end{array}$} & AU2 & 0.709 & 0.503 & \multirow[t]{3}{*}{0.542} & \multirow[t]{3}{*}{0.780} & \multirow[t]{3}{*}{0.792} \\
\hline & AU3 & 0.727 & 0.529 & & & \\
\hline & AU4 & 0.771 & 0.594 & & & \\
\hline
\end{tabular}

\section{Measurement model}

Confirmatory factor analysis (CFA) indicated that six items (PE4, EE4, SI1, SI2, FC4, and AU1) were candidates for elimination based on recommendations regarding the modification indices (greater than 10) and standardised residual matrix (greater than 3) (Hair et al., 2010). The resulting model produced indices that were a good fit (see Table 4). The results thus indicate that the proposed model achieves goodness-of-fit to the observed data.

Table 6 Factor Correlations

\begin{tabular}{lllllll}
\hline & FC & SI & EE & PE & IU & AU \\
\hline FC & 1 & & & & & \\
SI & $\mathbf{0 . 1 5 5}$ & 1 & & & & \\
EE & $\mathbf{0 . 8 2 3}$ & $\mathbf{0 . 1 8 3}$ & 1 & & & \\
PE & $\mathbf{0 . 4 7 6}$ & $\mathbf{0 . 3 2 3}$ & $\mathbf{0 . 6 6 6}$ & 1 & & \\
IU & $\mathbf{0 . 6 5 4}$ & $\mathbf{0 . 2 8 5}$ & $\mathbf{0 . 5 3 1}$ & $\mathbf{0 . 6 3}$ & 1 & \\
AU & $\mathbf{0 . 6 5 1}$ & $\mathbf{0 . 3 2 6}$ & $\mathbf{0 . 6 7 6}$ & $\mathbf{0 . 8 2 3}$ & $\mathbf{0 . 6 9 5}$ & 1 \\
\hline
\end{tabular}

Factor correlations less than 0.85 in bold 
Convergent and discriminant validity were then estimated to assess the construct validity of the measurement model. Convergent validity was measured by factor loadings $(>0.707)$, composite reliability $(>0.7)$, and average variance extracted (AVE) (>0.5) (Hair et al., 2010). The results are presented in Table 5 and indicate acceptable convergent validity and reliability (Cronbach's Alpha $>0.7$ ).

Discriminant validity measures the extent to which constructs are distinct (Bagozzi et al., 1991). As shown in Table 6, all the constructs were distinct because the correlation coefficients between factors were less than the suggested value of 0.85 (Kline, 2011).

\section{Structural model and hypotheses testing}

The next step was to test the structural model (Fig. 3). Structural equation modelling (SEM) is a comprehensive tool employed to test the hypothesised relationships between variables (Hair et al., 2010), which in this study were the relationships between UTAUT factors, behavioural intentions, and usage of Moodle at Hashemite University. Figure 3 shows the final structural model that result from applying the refinement criteria mentioned in measurement model section that contains 18 items.

The overall model was then examined. Based on the analysis of the structural model, frequently used measures of model fit are summarised in Table 7, the results of which indicate an acceptable fit to the data. Based on the results obtained using

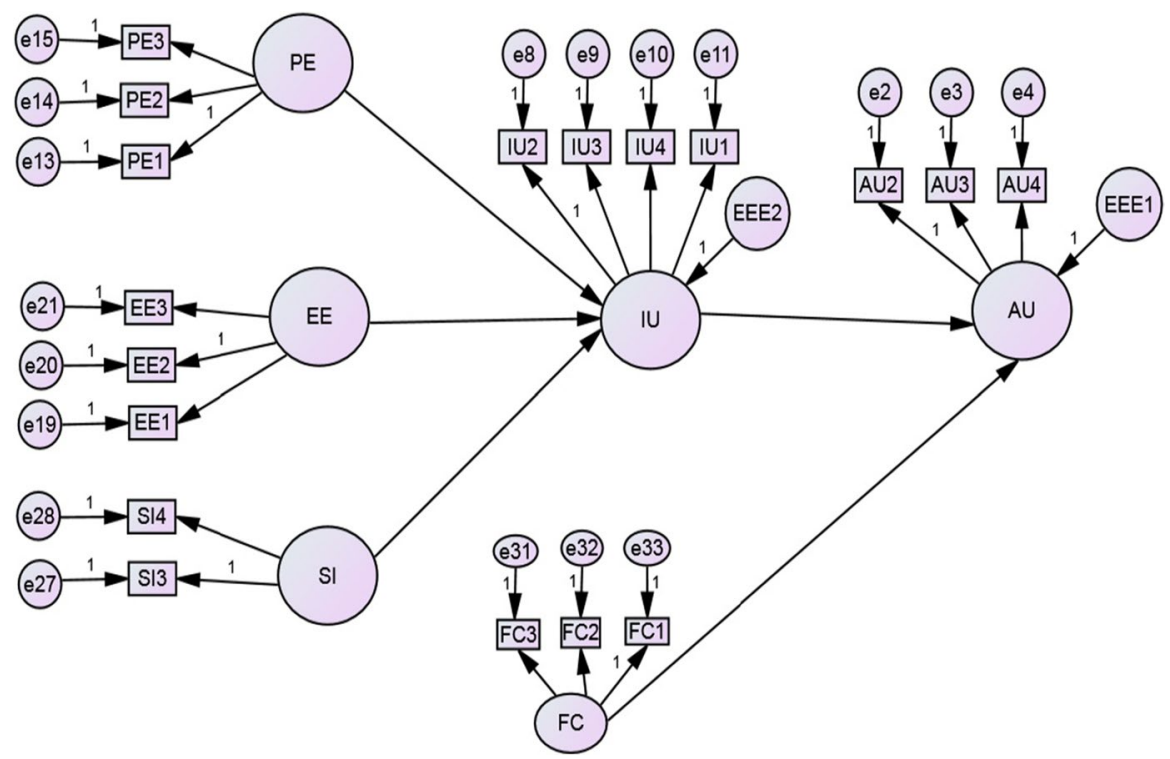

Fig. 3 Structural Model 
Table 7 Standardised Effects for the Model

\begin{tabular}{lllll}
\hline Factor & Determinant & $\begin{array}{l}\text { Direct } \\
\text { Effect }\end{array}$ & $\begin{array}{l}\text { Indirect } \\
\text { Effect }\end{array}$ & $\begin{array}{l}\text { Total } \\
\text { Effect }\end{array}$ \\
\hline Intention to Use & FC & - & - & - \\
$\left(\mathrm{R}^{2}=47.7\right)$ & SI & $\mathbf{0 . 1 0 6}$ & - & $\mathbf{0 . 1 0 6}$ \\
& EE & $\mathbf{0 . 3 1 9}$ & - & $\mathbf{0 . 3 1 9}$ \\
& PE & $\mathbf{0 . 3 9 6}$ & - & $\mathbf{0 . 3 9 6}$ \\
Actual Use & FC & $\mathbf{0 . 3 6 4}$ & - & $\mathbf{0 . 3 6 4}$ \\
$\left(\mathrm{R}^{2}=59.9\right)$ & SI & - & 0.056 & 0.056 \\
& EE & - & $\mathbf{0 . 1 6 8}$ & $\mathbf{0 . 1 6 8}$ \\
& PE & - & $\mathbf{0 . 2 0 9}$ & $\mathbf{0 . 2 0 9}$ \\
& IU & $\mathbf{0 . 5 2 8}$ & - & $\mathbf{0 . 5 2 8}$ \\
\hline
\end{tabular}

Effect sizes greater than 0.1 are in bold

AMOS 24 software, the final model can be expressed by two equations using nonstandardised regression coefficients:

$$
\begin{gathered}
\mathrm{IU}=0.135 \mathrm{SI}+0.318 \mathrm{EE}+0.506 \mathrm{PE} \\
\mathrm{R}^{2}=47.7 \text { Error variance }=52.3 \\
\mathrm{AU}=0.451 \mathrm{IU}+0.309 \mathrm{FC} \\
\mathrm{R}^{2}=59.9 \text { Error variance }=40.1
\end{gathered}
$$

In these structural equations, the path values are the regression coefficients. For example, $0.401\left(1-\mathrm{R}^{2}\right.$, where $\mathrm{R}^{2}$ is the coefficient of determination) is the error variance in the second equation.

This model explains approximately $47.7 \%$ of the variance in behavioural intentions and $59.9 \%$ of the variance in actual usage (see Table 7). This is relatively high, albeit below the level of $70 \%$ suggested by Venkatesh et al. (2003). Table 7 presents the standardised direct, indirect, and total effect implied by the model. For example, the major determinant of intention to use was perceived expectancy (PE) with a total effect of 0.396. The second determinant was effort expectancy (EE) with a total effect of 0.319 . The third determinant was social influence (SI) with a total effect of only 0.106 . All total effects were due to a direct effect. The two main determinants of actual usage were behavioural intentions (IU) and facilitating conditions (FC) with direct effects of 0.528 and 0.364 , respectively. The third, fourth, and fifth determinants were perceived expectancy, effort expectancy, and social influence with indirect effects of $0.209,0.168$, and 0.056 , respectively. According to Cohen's (1988) recommendations regarding the interpretation of effect size, students' behavioural intentions to use Moodle had a large total effect (greater than 0.5) on students'

Table 8 Results of Path Tests

\begin{tabular}{llllllll}
\hline Relationship & & Estimate & S.E. & C.R. & P & Comment \\
\hline IU & $<---$ & SI & .135 & .090 & 1.496 & .135 & Not Sig. \\
IU & $<---$ & EE & .318 & .108 & 2.944 & .003 & Sig. \\
IU & $<---$ & PE & .506 & .151 & 3.345 & $* * *$ & Sig. \\
AU & $<---$ & FC & .309 & .089 & 3.459 & $* * *$ & Sig. \\
AU & $<---$ & IU & .451 & .092 & 4.906 & $* * *$ & Sig. \\
\hline
\end{tabular}


Table 9 Summary of Hypotheses

\begin{tabular}{ll}
\hline Hypothesis & Result \\
\hline H1: Performance expectancy will affect the behavioural intention. & Supported \\
H2: Effort expectancy will affect the behavioural intention. & Supported \\
H3: Social influence will affect the behavioural intention. & Not Supported \\
H4: Facilitating condition will affect the use behaviour. & Supported \\
H5: Behavioural intention will affect the use behaviour. & Supported \\
\hline
\end{tabular}

behaviour while facilitating conditions had a medium total effect (greater than 0.3). In Table 7 , effect sizes greater than 0.1 are shown in bold.

Table 8 presents the path values, the critical ratio (C.R.) (or t-values = path values/standard error (S.E.)), and the significance level ( $p$ value). Four of the five paths were significant as the critical ratio (C.R.) exceeded 1.96 and the $\mathrm{p}$ value was less than 0.05 .

Table 9 presents a summary of the supported and non-supported hypotheses. Performance expectancy (Hypothesis 1) and effort expectancy (Hypothesis 2) significantly affected students' behavioural intentions to use Moodle. Social influence (Hypothesis 3) did not significantly affect students' behavioural intentions to use Moodle. Facilitating conditions (Hypothesis 4) and behavioural intention (Hypothesis 5) significantly affected students' usage of Moodle.

\section{Discussion and implications}

The primary objective of this research was to identify the factors in the UTAUT that affect students' adoption of an e-learning system in higher education. The results reveal that the UTAUT can explain students' behaviour regarding usage of the e-learning system and all except one of the relationships posited in the UTAUT were supported. Notably, social influence did not influence behavioural intentions, which is consistent with other findings in technology acceptance research (Jambulingam, 2013) and in e-learning and e-government contexts (Jaradat \& Banikhaled, 2013; Nassuora, 2012; AlShehri et al., 2013; AlImarah et al., 2013). However, it was contrary to the findings of Al-Adwan et al. (2018), Karahanna and Straub (1999) and Kim and Lee (2020).

This result implies that social influence is not significant predictor of behavioural intention that influence the actual use. The current digital generation are born in digital environment that decrease the need of instructor or peer influence (Jambulingam, 2013).

Performance expectancy was the most powerful predictor of behavioural intentions to use Moodle. This was in accordance with the findings of previous research (Anderson et al., 2006; Khechine et al., 2014; Kim \& Lee, 2020). As expected, the main concern for students was enhancing their level of academic performance and they perceived Moodle to be a technological tool that will help them achieve this. 
Given these findings, academics, experts, administrators, and e-learning system designers should focus on promoting the efficiency and efficacy of a system that enhances students' academic performance.

Effort expectancy was the second most important determinant of behavioural intentions. This finding was consistent with that of researchers who have applied the UTAUT to learning in Arab countries (Jaradat \& Banikhaled, 2013; Nassuora, 2012). In particular, Jaradat and Banikhaled found that effort expectancy exerted the most powerful effect on students' behavioural intentions to use the university website in Jordan. Nassuora found effort expectancy to be predictive of behavioural intentions to use mobile learning among Saudi students. Therefore, students who found Moodle easy to use have more positive behavioural intentions towards using the system. The same results have been found by researchers using a different adoption model (e.g., TAM) in information technology contexts (Davis, 1986; Venkatesh \& Davis, 2000; Abbad et al., 2009). When building and/or modifying the e-learning system, universities should therefore take this factor into consideration and make it as easy to use as possible (less effort) so that students are motivated to adopt it.

Facilitating conditions also appeared to support students in using Moodle. This is consistent with several previous studies (Al-Adwan et al., 2018; Iqbal \& Qureshi, 2012; Khechine et al., 2014; Maduku, 2015; Hadi \& Kishik, 2014; Kim \& Lee, 2020). Students will use Moodle when the necessary resources and technical support are perceived to be available. Universities should motivate students to use Moodle through the provision of training, documents, and technical support where needed. Supportive and knowledgeable staff should be available at any time to help students overcome any difficulties they may encounter.

Al-Shehri (2017) reached to the same conclusions about the effect of UTAUT factors on the behavioral intention and usage of the Desire2Learn (D2L) e-learning system in Saudi Arabia. The primary goal of his study was to assess the effectiveness of the D2L (e-learning) method based on student acceptance. The results showed that performance expectancy, effort expectancy, and facilitating conditions had a positive impact influence on behavior intention to use e-learning system. Social influence did not have any meaningful effect on behavioral intention for adopting an e-learning system.

Finally, behavioural intentions had the most direct and significant effect on students' usage of Moodle. The fact that behavioural intentions has a strong effect on usage shows that those with high levels of behavioural intentions had high levels of usage.

Abdekhoda et al. (2016), Moghavvemi et al. (2015), Alrawashdeh et al. (2012), Kim and Lee (2020), and AlShehri et al. (2013) found similar results regarding users' acceptance of new technologies. In addition, performance expectancy was the most important indirect determinant of students' behaviour. This suggests that students wanted to use Moodle because it helped them to improve their academic performance.

A clearer understanding of the determinants of behavioural intentions and the usage of Moodle by students will help decision makers in universities use the right technology and encourage students to engage with the system by building and designing a technological environment that will help them enhance their academic performance. This is especially important during a state of emergency such as the COVID-19 virus which has impelled educational institutions across the world to make use of e-learning systems. 


\section{Conclusion}

The primary objective of this research was to investigate the determinants of students' behaviour in relation to the use of e-learning systems in higher education. The results suggest that students' adoption and use of e-learning systems is predicted by their behavioural intentions, which are themselves affected by performance expectancy and effort expectancy. The results also indicate that facilitating conditions have a significant effect on student behaviour. In the context of higher education, this research affirms the utility of the UTAUT in predicting behavioural intentions and actual usage of e-learning systems by students in developing countries.

Given these results, universities should encourage students to use e-learning systems to enhance their academic performance as the successful implementation of the system depends on student acceptance. The developers of e-learning systems should also design effortless applications to motivate students to use the system. University management should ensure that all the required resources are available for students, designers, and faculty members when needed. This will help universities to react immediately in the event of an emergency such as COVID-19 s.

There are also some limitations in this research that should be addressed. First, the study focused only on students at one university in Jordan (Hashemite University); different results may be obtained when examining other e-learning systems used in different universities in the same country or in other developing countries. Second, potential moderators (age, gender, experience, and voluntariness) that could strengthen the prediction of students' behaviour were not taken into consideration. Finally, in this study, a self-reported measure provided by respondents was used to measure actual use, which might not be the best measure and the results may be influenced by common method bias. A more accurate measure would be to explore users' usage in a longitudinal study and control for actual usage of the system.

\section{References}

Abbad, M. M., Morris, D., \& De Nahlik, C. (2009). Looking under the bonnet: Factors affecting student adoption of e-learning systems in Jordan. International Review of Research in Open and Distributed Learning, 10(2).

Abdekhoda, M., Dehnad, A., Mirsaeed, S. J. G., \& Gavgani, V. Z. (2016). Factors influencing the adoption of E-learning in Tabriz University of Medical Sciences. Medical Journal of the Islamic Republic of Iran, 30, 457.

Ajzen, I. (1985). From intention to actions: A theory of planned behavior. Springer Verlag.

Al Mulhem, A. (2020). Exploring the Key Factors in the Use of an E-Learning System Among Students at King Faisal University, Saudi Arabia.

Al-Adwan, A. S., Al-Madadha, A., \& Zvirzdinaite, Z. (2018). Modeling students' readiness to adopt Mobile learning in higher education: An empirical study. International Review of Research in Open and Distributed Learning, 19(1).

AlImarah, A., Zwain, A., \& Al-Hakim, L. (2013). The adoption of E-government Services in the Iraqi HigherEducation context: An application of the UTAUT model in the University of Kufa. Journal of Information Engineering and Applications, 3(10), 77-84.

Almarabeh, T., \& Mohammad, H. (2013). E-learning in the Jordanian higher education system: Strengths, weakness, opportunities and threats. Journal of American Science, 9(3), 281-287. 
Al-Qeisi, K., Dennis, C., Hegazy, A., \& Abbad, M. (2015). How viable is the UTAUT model in a nonWestern context? International Business Research, 8(2), 204.

Alrawashdeh, T., Muhairat, M., \& Alqatawnah, S. (2012). Factors affecting acceptance of web-based training system: Using extended UTAUT and structural equation modeling. International Journal of Computer Science, Engineering and Information Technology (IJCSEIT), 2(2), 45-54.

Al-Shahrani, H. (2016). Investigating the determinants of mobile learning acceptance in higher education in Saudi Arabia (Doctoral dissertation, ).

Al-Shehri, M. (2017). The effectiveness of D2L system: An evaluation of teaching-learning process in the Kingdom of Saudi Arabia. International Journal of Advanced Computer Science and Applications, 8(1).

AlShehri, M., Draw, S. and AlGhamdi, R. (2013) Analysis of citizen acceptance of E-government Services: Applying the UTAUT Model [www] Available from: https://arxiv.org/abs/1304.3157. (Accessed on 4 May 2020).

Anderson, J. C., \& Gerbing, D. W. (1988). Structural equation modeling in practice: A review and recommended two-step approach. Psychological Bulletin, 103(3), 411-423.

Anderson, J. E., Schwager, P. H., \& Kerns, R. L. (2006). The drivers for acceptance of tablet PCs by faculty in a college of business. Journal of Information Systems Education, 17(4), 429-440.

Ashraf, S., Khan, T., \& Rehman, I. (2016). E-learning for secondary and higher education sectors: A survey. International Journal of Advanced Computer Science and Applications, 7(9), 275-283.

Bagozzi, R. P., Yi, Y., \& Phillips, L. W. (1991). Assessing construct validity in organizational research. Administrative Science Quarterly, 36(3), 421-458.

Biggs, J. (2003). Teaching for quality learning at university (2nd ed.). Society for Research in Higher Education \& Open University Press.

Bonk, C. (2016). Keynote: What is the state of e-learning? Reflections on 30 ways learning is changing. Journal of Open, Flexible, and Distance Learning, 20(2), 6-20.

Chang, K. M., \& Cheung, W. (2001). Determinants of the intention to use internet/www at work: A confirmatory study. Information and Management, 39(1), 1-14.

Chin, K.L. (1999) A study into students' perceptions of web-based learning environment. HERDSA Annual International Conference.

Chu, T. H., \& Chen, Y. Y. (2016). With good we become good: Understanding e-learning adoption by theory of planned behavior and group influences. Computers \& Education, 92, 37-52.

Cohen, J. (1988). Statistical power analysis for the behavioral sciences. Lawrance Erlbaum Associates.

Davis, F. D. (1986) A technology acceptance model for empirically testing new end-user information systems: Theory and results. (Doctoral dissertation, Sloan School of Management, Massachusetts Institute of Technology).

Davis, F. D. (1993). User acceptance of information technology: System characteristics, user perceptions and behavioral impacts. International Journal of Man-Machine Studies, 38(1), 475-487.

Deb, S. (2011). Effective distance learning in developing countries using mobile and multimedia technology. International of Multimedia and Ubiquitous Engineering, 6(2), 33-40.

Dwivedi, Y. K., Rana, N. P., Jeyaraj, A., Clement, M., \& Williams, M. D. (2019). Re-examining the unified theory of acceptance and use of technology (UTAUT): Towards a revised theoretical model. Information Systems Frontiers, 21(3), 719-734.

Farid, S., Ahmad, R., Niaz, I. A., Arif, M., Shamshirband, S., \& Khattak, M. D. (2015). Identification and prioritization of critical issues for the promotion of e-learning in Pakistan. Computers in Human Behavior, 51, 161-171.

Fillion, G., Braham, H., \& Ekionea, J. P. B. (2012). Testing UTAUT on the use of ERP systems by middle managers and end-users of medium-to large-sized Canadian enterprises. Academy of Information and Management Sciences Journal, 15(2), 1-28.

Fishbein, M., \& Ajzen, I. (1975). Belief, attitude, intention and behavior: An introduction to theory and research. Addison-Wesley.

Forza, C., \& Filippini, R. (1998). TQM impact on quality conformance and customer satisfaction: A causal model. International Journal of Production Economics, 55(1), 1-20.

Gogus, A., \& Nistor, N. (2012, October). Educational technology acceptance across cultures: A validation of the unified theory of acceptance and use of technology in the context of turkish national culture. Turkish Online Journal of Educational Technology - TOJET, 11, 394-408.

Gould, J. D. C., \& Lewis, D. (1985). Designing for usability: Key principles and what designers think. Communications of the ACM, 28(3), 300-311. 
Greenspoon, P. J., \& Saklofske, D. H. (1998). Confirmatory factor analysis of the multidimensional students' life satisfaction scale. Personality and Individual Differences, 25(5), 965-971.

Hadi, F., \& Kishik, A. (2014). Acceptance of mobile learning among university students in Malysia. Journal of Computing and organizational Dynamics, 1(1), 1-14.

Hair, J., Black, B., Babin, B., Anderson, R. E., \& Tatham, R. L. (2006). Multivariate data analysis (6th ed.). Prentice Hall.

Hair, J. F., Black, W. C., Babin, B. J. \& Anderson, R. E. (2010) Multivariate data analysis: A global perspective, 7th Edition Upper Saddle River: Pearson Education.

International Telecommunication Union reports (2017) Country profile [www]. Available from: http:// www.itu.int/net4/itu-d/icteye/CountryProfile.aspx. (Accessed on 25 July 2020).

Internet World Stats. ICT Facts and Figures (2020). Retrieved July 2020 from https://www.internetwo rldstats.com/stats.htm.

Iqbal, S., \& Qureshi, I. (2012). M-learning adoption: A perspective from a developing country. The International Review of Research in Open and Distributed Learning, 13(3), 148-164.

Jaber, O. A. (2016). An examination of variables influencing the acceptance and usage of E-learning systems in Jordanian higher education institutions (Doctoral dissertation, Cardiff Metropolitan University).

Jambulingam, M. (2013). Behavioural intention to adopt mobile technology among tertiary students. World Applied Sciences Journal, 22(9), 1262-1271.

Jaradat, M. I. R. M., \& Banikhaled, M. (2013). Undergraduate students adoption of website-service quality by Applying the unified theory of acceptance and use of technology (UTAUT) in Jordan. International Journal of Interactive Mobile Technologies, 7(3), 22-29.

Johnson, S. D., Aragon, S. R., Shaik, N., \& Palma-Rivas, N. (2000). Comparative analysis of learner satisfaction and learning outcomes in online and face-to-face learning environments. Journal of Interactive Learning Research, 11(1), 29-49.

Johnson, M. P., Zheng, K., \& Padman, R. (2014). Modeling the longitudinality of user acceptance of technology with an evidence-adaptive clinical decision support system. Decision Support Systems, 57, 444-453.

Karahanna, E., \& Straub, D. (1999). The psychological origins of perceived usefulness and ease of use. Information and Management, 35(4), 237-250.

Khechine, H., Lakhal, S., Pascot, D., \& Bytha, A. (2014). UTAUT model for blended learning: The role of gender and age in the intention to use webinars. Interdisciplinary Journal of E-Learning and Learning Objects, 10(1), 33-52.

Kim, J., \& Lee, K. S. S. (2020). Conceptual model to predict Filipino teachers' adoption of ICT-based instruction in class: using the UTAUT model. Asia Pacific Journal of Education, 1-15.

Kim, B., \& Park, M. J. (2018). Effect of personal factors to use ICTs on e-learning adoption: Comparison between learner and instructor in developing countries. Information Technology for Development, 24(4), 706-732.

Kline, R. B. (2011). Principles and practice of structural equation modeling (3rd ed.). The Guilford Press.

Lew, S. L., Lau, S. H., \& Leow, M. C. (2019). Usability factors predicting continuance of intention to use cloud e-learning application. Heliyon, 5(6), e01788.

Louho, R., Kallioja, M., \& Oittinen, P. (2006). Factors affecting the use of hybrid media applications. Graphic Arts in Finland, 35(3), 11-21.

Maduku, D. K. (2015). An empirical investigation of students' behavioural intention to use e-books. Management Dynamics: Journal of the Southern African Institute for Management Scientists, 24(3), 3-20.

Maldonado, U. P. T., Khan, G. F., Moon, J., \& Rho, J. J. (2011). E-learning motivation and educational portal acceptance in developing countries. Online Information Review, 35(1), 66-85.

Martínez-Cerdá, J. F., Torrent-Sellens, J., \& González-González, I. (2020). Socio-technical e-learning innovation and ways of learning in the ICT-space-time continuum to improve the employability skills of adults. Computers in Human Behavior, 107, 105753.

Moghavvemi, S., Mohd Salleh, N. K., Sulaiman, A., \& Abessi, M. (2015). Effect of external factors on intention-behaviour gap. Behaviour \& Information Technology, 34(12), 1171-1185.

Moreira, J., Monteiro, A., \& Machado, A. (2017). Higher education distance learning and e-learning in prisons in Portugal. Media Education Research Journal, xxv, 51, 39-49.

Nassuora, B. (2012). Students acceptance of Mobile learning for higher education in Saudi Arabia. International Journal of Learning Management Systems, 1(1), 1-9. 
Navarrete, R., Luján-Mora, S., and Peñafiel, M. (2016) Use of Open Educational Resources in E-learning for Higher Education. Third International Conference on eDemocracy \& eGovernment (ICEDEG 2016), p. 177-183, Quito (Ecuador), March 30-April 12016.

Nickerson, R. S. (1981). Why interactive computer systems are sometimes not used by people who might benefit from them. International Journal of Man-Machine Studies, 3(15), 469-483.

Park, S. Y. (2009). An analysis of the technology acceptance model in Understanding University Students' behavioral intention to use e-learning. Educational Technology \& Society, 12(3), 150-162.

Ramsden, P. (1998). Studying learning: Improving teaching. Improving learning: new perspectives, London: Kogan Page, 13-31.

Rawat, B., \& Dwivedi, S. K. (2019). Discovering Learners' characteristics through cluster analysis for recommendation of courses in E-learning environment. International Journal of Information and Communication Technology Education (IJICTE), 15(1), 42-66.

Rogers, E. M. (1983). Diffusion of innovations (3rd ed.). Free Press.

Salim, B. (2012). An application of UTAUT model for acceptance of social Media in Egypt: A statistical study. International Journal of Information Science, 2(6), 92-105.

Sánchez-Prieto, J. C., Olmos-Migueláñez, S., \& García-Peñalvo, F. J. (2017). MLearning and pre-service teachers: An assessment of the behavioral intention using an expanded TAM model. Computers in Human Behavior, 72, 644-654.

Sathye, M. (1999). Adoption of internet banking by Australian consumers: An empirical investigation. International Journal of Bank Marketing, 17(7), 324-334.

Sharma, S. K., Gaur, A., Saddikuti, V., \& Rastogi, A. (2017). Structural equation model (SEM)-neural network (NN) model for predicting quality determinants of e-learning management systems. Behaviour \& Information Technology, 36(10), 1053-1066.

Succi, M.J. \& Walter, Z.D. (1999) Theory of user acceptance of information technologies: an examination of health care professionals. Proceedings of the 32nd Hawaii International Conference on System Sciences (HICSS), 1-7.

Thomas, T., Singh, L., \& Gaffar, K. (2013). The utility of the UTAUT model in explaining mobile learning adoption in higher education in Guyana. International Journal of Educational and Development using Information and Communication technology, 9(3), 71-85.

Uğur, N. G., \& Turan, A. H. (2018). E-learning adoption of academicians: A proposal for an extended model. Behaviour \& Information Technology, 37(4), 393-405.

Vasconcelos, P., Furtado, E. S., Pinheiro, P., \& Furtado, L. (2020). Multidisciplinary criteria for the quality of e-learning services design. Computers in Human Behavior, 107, 105979.

Venkatesh, V., \& Davis, F. (2000). A theoretical extension of the technology acceptance model: Four longitudinal field studies. Management Science, 46(2), 186-204.

Venkatesh, V., Morris, M. G., Davis, G. B., \& Davis, F. D. (2003). User acceptance of information technology: Toward a unified view. Management Information Systems Quarterly, 27(3), 426-478.

Venkatesh, V., Thong, J. Y., Chan, F. K., Hu, P. J. H., \& Brown, S. A. (2011). Extending the two-stage information systems continuance model: Incorporating UTAUT predictors and the role of context. Information Systems Journal, 21(6), 527-555.

Venkatesh, V., Thong, J. Y., \& Xu, X. (2012). Consumer acceptance and use of information technology: extending the unified theory of acceptance and use of technology. MIS quarterly, 157-178.

Vershitskaya, E. R., Mikhaylova, A. V., Gilmanshina, S. I., Dorozhkin, E. M., \& Epaneshnikov, V. V. (2020). Present-day management of universities in Russia: Prospects and challenges of e-learning. Education and Information Technologies, 25(1), 611-621.

Violante, M. G., \& Vezzetti, E. (2015). Virtual interactive e-learning application: An evaluation of the student satisfaction. Computer Applications in Engineering Education, 23(1), 72-91.

Webster, J., \& Hackley, P. (1997). Teaching effectiveness in technology-mediated distance learning. Academy of Management Journal, 40(6), 1282-1309.

Publisher's note Springer Nature remains neutral with regard to jurisdictional claims in published maps and institutional affiliations. 